Marcin Böhm (Opole)

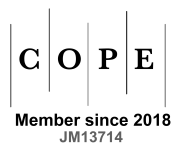

(iD) https://orcid.org/0000-0002-5393-3176

\title{
INGVAR THE FAR-TRAVELLED: BETWEEN THE BYZANTIUM and Caucasus. A Maritime Approach to Discussion
}

$\mathrm{I}^{\mathrm{n}}$ ngvar the Far-Travelled (old Norse: Yngvarr víðförli), who lived between $1010-1041$, is one of the mysterious figures in the history of the $11^{\text {th }}$ century Sweden. He was one of the last leaders of the Scandinavians who tried his luck in the east, and more specifically on the eastern coast of the Black Sea and the Caucasus. The mystery of this character arises from a small number of sources detailing his life. Ingvar is only mentioned by name on Swedish runic stones, in a Saga describing his life, and in reports from Icelandic annals. Therefore, facing the researchers is an extremely difficult task: namely, to determine both his origins and find out about his life, the end of which Ingvar met in the east ${ }^{1}$. This discussion started at the beginning of the $20^{\text {th }}$ century and is still going on. Of greatest interest to this paper are those episodes from Ingvar's life which are related to seafaring since they may shed a new light on the accounts of his journey in the context of the $11^{\text {th }}$-century Byzantium.

Some personal information about Ingvar should be presented here. We know very little about his birth date and childhood. Historians have formulated a number of theories about his origin:

- he may have been the son of Eymundr, who was a son of Swedish chieftain named Áki, while his mother may have been the daughter of Swedish king Eric the Victorious;

\footnotetext{
${ }^{1}$ J. ShePard, Yngvarr's Expedition to the East and a Russian Inscribed Stone Cross, SBVS 21, 1982, p. 222-292; M.G. LaRsson, Yngvarr's Expedition and the 'Georgian Chronicle', SBVS 22, 1986, p. 98-108; IDEM, Early Contacts between Scandinavia and the Orient, SRJ 9, 2011, p. 126-127; D.I. McGinnis, The Vikings in the East: Ingvars sagavifförla, [in:] A Selection from the Papers Presented at the First Annual Meeting Held at Ottawa 1982, ed. E.W. LaIne, Ottawa 1983, p. 79; O. Von Firesen, Hvem var Yngvarr enn vidforli?, For 5, 1910, p. 199-209; S. WierzBIŃski, U boku bazyleusa. Frankowie i Waregowie w cesarstwie bizantyńskim w XI w., Łódź 2019 [= BL, 37], p. 88-89; С. МАРКАРян, По поводу личности предводителя дружины викингов на Кавказе в ХІ веке, РВН 103, 1, 2000, p. 154-155; S. BLöndal, Varangians of Byzantium. An Aspect of Byzantine Military History, trans. B.S. BenEDIKZ, Cambridge 1978, p. 105.
} 
- his father Eymundur may have been a son of Eric the Victorius, and brother of Olaf Skötkonung;

- the last one suggests that Ingvar was a son of King Edmund the Old, and grandson of Olaf Skötkonung².

The first group of sources, the Icelandic annals, are associated with the only certain fact about Ingvar, namely the date of his death. Under the year 1041, the following phrase appears: Dáinn Yngvarr vífförli... or ...Andadiz Ynguar vidforli . The quoted annals do not come from Ingvar's days but are much later. The information about the death of our hero was taken from the compilation made by Sturla Pórðarson (1214-1284) in the late $13^{\text {th }}$ century ${ }^{4}$. This writer of the Icelandic Sagas was also a historian of his time, which is why the date of Ingvar's death should be treated as credible. Why are Ingvar's age and death important for maritime affairs? I will discuss this later in this paper.

Another extremely reliable group of sources is runic stones. The 26 stones on which references are made to the Ingvar expedition come from Uppland, Södermanland, Västmanland, Östergötland, i.e. from the lands in eastern Sweden. Their content has been the subject of discussion for many years, especially because they are among the few runic stones which contain some references to Serkland, the land of the Saracens ${ }^{5}$. The runic stones most important for my argument have the following content:

\section{U 439}

Latin transliteration:

[harlaif $\times$ auk $\times$ purkarpr $\times$ litu $\times$ raisa $\times$ stain $\times$ pina at $\times$ sabi fapur $\sin \times$ is $\|$ sturpi $\times$ austr $\times$ skibi $\times$ map ikuari a/a| |askalat-/skalat-]

Old Norse transcription:

Hærlæif ok Porgærðr letu ræisa stæin penna at Sæbiorn, faður sinn. Es styrði austr skipi með Ingvari a Æistaland(?) / Særkland[i](?).

\footnotetext{
${ }^{2}$ O. Pritsak, The Origin of Rus', vol. I, Old Scandinavian Sources other than the Sagas, Cambridge Mass. 1981, p. 425-430; M.G. LARsson, Ingvar the Fartravellers Journey: Historical and Archaeological Sources, [in:] Between East and West. Early Contacts between Scandinavia and Caucasus, ed. IDEM, Uppsala-Rimbo 2013, p. 37-38.

${ }^{3}$ Lögmannsannáll (ásamt Nýjaannál), ed. G. Jónsson, Reykjavík 1948, http://heimskringla.no/Lögmannsannáll_(ásamt_Nýjaannál) [10 XII 2018]; Konungs annáll "Annales islandorum regii", 22, 9, ed. H.B. Goodwin, Uppsala 1906, p. 100; Flateyjarbok, ed. G. Vigfússon, C.R. Unger, Christiana 1868, p. 507.

${ }^{4}$ O. Pritsak, The Origin..., p. 424.

${ }^{5}$ Ibidem, p. 451-453; M.G. LARsson, Ingvarstågets arkeologiska bakgrund, For 81, 1986, p. 99-100.
} 


\section{English translation:}

Herleif and Porgerðr had this stone raised in memory of Sæbjôrn, their father, who steered a ship east with Ingvar to Estonia(?) / Serkland(?).

\section{U 654}

Latin transliteration:

+ a--itr: auk ${ }^{\star} \mathrm{ka}(\mathrm{r})$ auk: kiti: auk: -[1]isi: auk ${ }^{*}$ tiarfr: ris[t]u: stain: pena: aftir: kunlaif: fopur $\sin$ is $\mathrm{u}[\mathrm{a}] \mathrm{s} \operatorname{nus}(\mathrm{t})(\mathrm{r}){ }^{*} \mathrm{~m}[\mathrm{i}](\mathrm{p})$ ikuari: tribin kup: hialbi: $\mathrm{o}(\mathrm{t})$ paira al-ikr| |raistik ${ }^{*}$ runar is kuni + ual $^{\star}$ knari stura

\section{Old Norse transcription:}

A[ndv] ettr ok Karr ok <kiti> ok [B]lesi ok DiarfR ræistu stæin penna æftiR Gunnlæif, faður sinn. Es vas austr með Ingvari drepinn. Guð hialpi and pæiRa. Al[r]ikR(?) ræist-ek runar. Es kunni val knærri styra.

$$
\text { English translation: }
$$

Andvéttr and Kárr and <kiti> and Blesi and Djarfr raised this stone in memory of Gunnleifr, their father, who was killed in the east with Ingvar. May God help their spirits. Alríkr(?), I carved the runes. He could steer a cargo-ship well ${ }^{7}$.

\section{U778}

Latin transliteration:

pialfi $\times$ auk $\times$ hulmnlauk $\times$ litu $\times$ raisa $\times$ staina pisa $\times$ ala $\times$ at baka $\times$ sun $\sin \times$ is ati $\times$ ain $\times$ sir $\times$ skib $\times$ auk $\times$ austr $\times \operatorname{stu}[$ rpi $\times]$ i $\times$ ikuars $\times$ lip $\times$ kup hialbi $\times$ ot $\times$ baka $\times$ ask $(i) l \times$ raist

Old Norse transcription:

Pialfi ok Holmlaug letu ræisa stæina pessa alla at Banka / Bagga, sun sinn. Es atti æinn seR skip ok austr styrði i Ingvars lið. Guð hialpi and Banka / Bagga. Æskell ræist.

\section{English translation:}

"Pjalfi and Holmlaug had all of these stones raised in memory of Banki / Baggi, their son, who alone owned a ship and steered to the east in Ingvar's retinue. May God help Banki's / Baggi's spirit. Áskell carved ${ }^{8}$.

Sö 335

Latin transliteration:

u ulf=ui: raisti: stain pana| |at brupur sin: u:snikin san furs: a:ust:arla: map: i:ikn:u:ari: ksibari hulmstains

Old Norse transcription:

UlfR(?) ræisti stæin penna at broður sinn Osnikin, saR fors austarla með Ingvari, skipari Holmstæins.

${ }^{6}$ Entry U 439 in Rundata 3.1 for Windows, http://www.nordiska.uu.se/forskn/samnord.htm [10 XII 2018] (cetera: Rundata); Sveriges Runinskrifter, VII, Upplands Runinskrifter del 2, ed. E. WesséN, S. Jansson, Stockholm 1943-1946, p. 232-233.

${ }^{7}$ Entry U 654 in Rundata; Sveriges Runinskrifter, VIII, Upplands Runinskrifter del 3, ed. E. WesséN, S. JANSSON, Stockholm 1949-1951, p. 112-116.

${ }^{8}$ Entry U 778 in Rundata; Sveriges Runinskrifter, VIII..., p. 357-361. 


\section{English translation:}

Ulfr(?) raised this stone in memory of his brother Ósníkinn. He travelled to the east with Ingvar; (he was) Holmsteinn's seaman.

The runic stones quoted above, besides valuable information in the form of the names of the participants of the Ingvar expedition, also provide us with data about the ships participating in it. On three of the stones, terms such as skipi / skip / skipari appear, and one stone features the term knoerri. The term skip can be translated as ship ${ }^{10}$. Therefore, this name could denote all of the ships used by the Scandinavians for commercial purposes as well as for the expeditions of plunder. The term knarr is much more precise. This type of vessel was a transport ship, about $16.5 \mathrm{~m}$ long and $4.8 \mathrm{~m}$ wide, capable of transporting more than 20 tons of goods ${ }^{11}$.

The most important source and also the most controversial one is the Ingvar Saga (Yngvars saga vífförla) ${ }^{12}$. Nowadays, the authorship of this saga is ascribed to Oddr Snorrason, who wrote down his text in Latin around $1200^{13}$. Odd was a zealous Christian Benedictine monk at the Pingeyrarklaustur, which was founded at Pingeyrar in Iceland after 1133, meaning that the Saga was written over a century after Ingvar's expedition. This important account of the journey to the east is full of Christian allegories and quasi-mythological descriptions of clashes with supernatural beings, giants, or dragons. We know that Yngvars saga viðförla presents a subjective point of view of a Christian monk, but it is also a historical source containing some historical figures or geographical concepts. This is why the Saga cannot be rejected on many counts, offering, for instance, insights into the events and terminology related to shipping and fighting at sea.

The Saga indicates that Ingvar was related by birth and had family ties to the rulers of Sweden, and from early childhood was taught about shipping. His father, Eymundr, was also associated with the sea. This is confirmed in the Saga when a mention is made of how Ingvar's father was exiled from home. Ingigerd, the daughter of King Olaf, secretly provided one ship on which he fled Sweden, escaping the wrath of her father (...fekk Ingigerðr honum skip á laun... / Ingigerd

\footnotetext{
${ }^{9}$ Entry Sö 335 in Rundata; Sveriges Runinskrifter, III, Södermanlands Runinskrifter, ed. E. BRATE, E. WESSÉN, Stockholm 1924-1936, p. 320-321.

${ }^{10}$ B. ElLertsson, Íslensk-pýsk orðabók. Isländisch-Deutsches Wörterbuch, Reykjavik 1993, p. 365; J. JESCH, Ships and Men in the Late Viking Age. The Vocabulary of Runic Inscriptions and Skaldic Verse, Woodbridge 2008, p. 120-123.

${ }^{11}$ J. Jesch, Ships..., p. 128-132; I. Atkinson, The Viking Ships, Cambridge 1980, p. 22-24.

${ }^{12}$ In this paper I have used the electronic versions of Ingaga saga, available online: Yngvars saga viððförla, http://heimskringla.no/wiki/Yngvars_saga_víðförla [10 XII 2018]; Yngvars saga viðförla, https://www.snerpa.is/net/forn/yngvar.htm [10 XII 2018].

${ }^{13}$ Oddr Snorrason, The Saga of Olaf Tryggvason, trans. T.M. Andersson, ed. K. Bragadóttir, Ithaca 2003, p. 3; M. Clunies Ross, Old Icelandic Literature and Society, Cambridge 2000, p. 306-308; D.I. McGinnis, The Vikings..., p. 85, note 1; J. ShePard, Yngvarr's..., p. 222-223.
} 
secretly provided him with a ship $)^{14}$. When Ingigerd married Jaroslav the Wise, whom the source refers to as Jarizleif, Eymundr went to Holmgard (Novgorod), where he enlisted in the service of the husband of his old lover flame. It brought him wealth and also ensured his safe return to Sweden ${ }^{15}$. The Saga mentions that Ingvar stayed in his father's house until he was 9 years old. Then, he joined the service of King Olaf and befriended his son, Onund. As a result, he reconciled his parent with his ruler, which was reflected in the gifts that Ingvar received from King Olaf: a good horse, a gilt saddle, and a ship (Pá gaf konungr Yngvari góðan hest ok söðul gylltan ok skip fagrt / Then the king gave Ingvar a good horse, a gilt saddle and a fine ship $)^{16}$. Of course, Ingvar gave these presents to his father, but he remained in the service of Olaf. In spite of Ingvar's young age, the King later gave him and Onund the mission to collect the tribute from the Semigallians. They were given three ships for this task (...primr skipum... / three ship ${ }^{17}$. Ingvar carried out this mission excellently, despite the fact that he had to fight with some Semigallians chieftains.

An armed expedition to the other side of the Baltic Sea was probably a breakthrough in Ingvar's career. At the peak of his popularity in Sweden, he decided to recruit volunteers and mount his own expedition. He managed to collect thirty ships (...prjá tigi skipa... / thirty ships), with full equipment ${ }^{18}$. Spearheading the fleet, he went to the east, to Jaroslav the Wise, to Garðaríki, where he stayed for three years, learning languages and the hydrography of the rivers of the Kievan Rus. The Saga mentions Ingvar's particular interest in three rivers flowing through the lands of the Rus. The central one was the largest and it was chosen by Ingvar, who wanted to know its length. Ingvar's fleet left Garðaríki, and the commander was accompanied by four companions: Hjalmvigi, Soti, Ketil, called Garda-Ketil an Islander, and Valdimar ${ }^{19}$. The thirty ships that left with Ingvar down the river experienced various mythical events. Probably the most interesting is the story of one of Ingvar's ships, commanded by two priests. Their ship was destroyed by the dragon Jakulus, who used its venom against it (Ok er Jakúlus kom yfir skip pat, sem prestar tveir stýrðu, pá spjó hann svá eitri, at boeði týndust skip ok menn / And when Jakulus came over the ship that was captained by two priests, he spewed such venom that both ship and men were destroyed ${ }^{20}$. Finally, after many days of traveling down the river, Ingvar reached the city of Citopolis, ruled by Queen Silkisif. At her invitation, Ingvar wintered in this place, as did his ships, which were brought ashore there by the inhabitants of the city. Later in this chapter,

\footnotetext{
${ }^{14}$ Yngvars saga víðförla, 2.

${ }^{15}$ Yngvars saga vídförla, 3.

${ }^{16}$ Yngvars saga víðförla, 3.

${ }^{17}$ Yngvars saga víðförla, 4.

${ }^{18}$ Yngvars saga víðförla, 5.

${ }^{19}$ Yngvars saga vífförla, 5.

${ }^{20}$ Yngvars saga víðförla, 5.
} 
the Saga describes Ingvar and his warriors' springtime journey down the river, which included negotiating rapids on two occasions. Having succeeded, at the end of summer, the Scandinavians reached Heliopolis (Heliópólim), whose ruler was King Jolf, and they were stopped there by his boats ${ }^{21}$. As guests of King Jolf, Ingvar and his people, along with their ships, spent the next winter there. Their ships were brought to the city for the winter period by inhabitants of Heliopolis. King Jolf shared with Ingvar his knowledge about the sources of the river, and also gave him a piece of advice: En í pessi áinni, er pú hefir farit eptir, liggja úti illgerðamenn á stórum skipum ok hafa öll skipin hulin reyri, svá at menn hyggja pat eyjar, ok hafa alls konar vápn ok skoteld, ok meir eyða peir mönnum með eldi en vápnum / But in this river, which you have gone up to, there lie evil men on large ships, and all the ships have hidden, so that men think about the islands, and have all kinds of weapons and fire, and more they destroy men with fire than the weapons ${ }^{22}$.

Ingvar, for his part, promised that he would support Jolf against his brother Bjolf as soon as he returned from the expedition he had planned for many years. Bjolof was more powerful than the king and had done a lot of damage to him. That is why Jolf sought allies against him. In the following spring, Ingvar went further, and it took him several months to build a canal that allowed his ships to sail past the next obstacle on the river ${ }^{23}$. Later on, in addition to meeting the mythical giants, Ingvar's fleet was involved in another interesting encounter. At the fork of the river, the Scandinavians were attacked by pirates, who masked their ships as five floating islands. One of the floating islands began the fight throwing stones at Ingvar's ships. It did not quite impress the Scandinavians, who hid behind the shields and then responded firing their own arrows. The pirates noticed this and changed their tactics, deploying a flamethrower that burned one of Ingvar's ships ${ }^{24}$. At this point, the Saga recalls Ingvar's heroic shot with a bow, which led to the explosion of a firetube, the destruction of this island ship, and the death of its crew. In a similar way, he destroyed the other four floating pirate islands ${ }^{25}$.

Later, Ingvar arrived at the source of the river and returned to Jolf. The Scandinavians returned to Heliopolis to assist the king against his brother Bjolf. Ingvar's help was decisive for the success of Jolf, who drove his brother away, and then attacked his Scandinavian allies. This surprised the Viking chieftain, who had previously predicted that he could be betrayed. This is why he had prepared caltrops, which his people scattered, slowing down the movement of the new enemy ${ }^{26}$.

${ }^{21}$ Yngvars saga viðförla, 5; G. Glazyrina, On Heliopolis in Ingvars saga viððörla, [in:] Scandinavian and Christian Europe in the Middle Ages. Papers of the $12^{\text {th }}$ International Saga Conference, ed. R. SimeK, J. Meurer, Bonn 2003, p. 175-178.

${ }^{22}$ Yngvars saga vídförla, 5.

${ }^{23}$ Yngvars saga víðförla, 6.

${ }^{24}$ Yngvars saga víförla, 6.

${ }^{25}$ Yngvars saga víðförla, 6.

${ }^{26}$ Yngvars saga víðförla, 7. 
On the way back to Silkisif, Ingvar and his crew caught an infectious disease which also led to the death of the leader of the expedition. It took place in 1041, when Ingvar was 25 years old (En pá er Yngvarr andaðist, var liðit frá burð Jesú Kristí MXL ok einn vetr. Pá var hann hálfpritugr, er hann dó / And when Yngvar breathed his last, 1041 years had passed since the birth of Jesus Christ. He was twenty-five when he died). His companions and the remaining 12 ships reached Citopolis (Citópolim) carrying his body ${ }^{27}$. The expedition, now without its leader, disintegrated. Ketil went to the Kievan Rus with one ship, while Valdimar sailed to Miklagard with another. The author of the Saga did not describe what happened to the other crews and ships ${ }^{28}$.

The last extremely important source is materials of Georgian origins. This is a short piece of information worth quoting in its entirety.

Varangs came, 3,000 strong, and he established them at Bashi.
Bagrat took with him seven hundred men and advanced with the
army of the interior. These Varangs did not wait for the Mesxs.
They came to grips at the entrance to the forest of Sasiret'i. The
army of the interior withdrew; and in that battle Abuser was captured,
and the other magnates with him. They were unable to fight
the Varangs. Liparit gave them servants who prepared food. In
this way they crossed the (chain) of Lixi. ${ }^{29}$

Thanks to this chronicle, we know that the Varangians came in the strength of 3,000 warriors and set up their camp in Bashi with the consent of Bagrat (Bashi is a place located at the mouth of the Rioni River, in Western Georgia). Bagrat IV (1018-1072, King of Georgia) incorporated 700 of these soldiers into his forces and engaged an army of rebels who had rose against his authority. The Varangians clashed with the enemy just outside the forest in Sasireti (today in the Shida Kartli region, near the city of Kaspi, in central-eastern Georgia). Bagrat's army was destroyed and his people were captured by Liparit (Liparit IV of Kldekari, 1030-1059; Kldekari is located today in the Kvemo Kartli region in southern Georgia). Left alone, the Varangians were unable to resist his army. Liparit sent the Varangians some servants, who prepared food for them, and later allowed them to cross the Lixi mountain range. From the Georgian source, we do not learn anything about any ships of the Varangians who arrived in Georgia in 1040s. The only certain information is that they landed at the mouth of the Rioni River and then crossed the mountain range, heading east.

\footnotetext{
${ }^{27}$ Yngvars saga víðförla, 8.

${ }^{28}$ Yngvars saga víðförla, 8.

${ }^{29}$ Rewriting Caucasian History. The Medieval Armenian Adaptation of the Georgian Chronicles. The Original Georgian Texts and the Armenian Adaptation, ed. et trans. R.W. Thomson, Oxford 1996, p. 293.
} 
Sigfus Blöndal suggested linking the events described in this source with facts related to Ingvar's expedition ${ }^{30}$. Mats G. Larsson used data from this chronicle to reconstruct the possible path of Ingvar's expedition, speculating that the Viking chieftain reached the Black Sea via the rivers of the Kievan Rus, and then went to Georgia, where he used local rivers (Rioni, Kvirila, Tscheremila, and Mktvari) to reach the Caspian Sea and the lands of the Saracens (Serkaland) ${ }^{31}$. The same author also suggests that Ingvar's expedition was accompanied by between 500 and 1,000 Swedes ${ }^{32}$. At the turn of the $21^{\text {st }}$ century, a group of Swedish shipbuilders and researchers set out on a journey to reconstruct the Scandinavian passage to the Caspian Sea through the Caucasus, proving that such a trip was possible with the use of small and light boats ${ }^{33}$. Some scholars also consider scenarios in which Ingvar took part in the great expedition of the Rus against Constantinople in 1043, not in the battles in Georgia, or even move the date of Ingvar's expedition to early $1030 \mathrm{~s}^{34}$. Jonathan Shepard, however, rejects M.G. Larsson's hypothesis which links Ingvar to the Battle of Sasiret'i, because the Georgian Chronicle dates this clash to $1045^{35}$. J. Shepard's skepticism in the case of Ingvar's journey towards the Caucasus is justified because M.G. Larsson's theory makes a mention of the Varangians' activity in Georgia, and somewhat too literally links this data to facts and places from the Saga.

If the reports from the Georgian source are rejected, it will be necessary to rely on the much later Yngvars saga vífförla and the runestones for matters related to seafaring. Thanks to these two sources, we know what type of vessel was used by Ingvar's fleet. Being a ship-boat-type, skip was a vessel smaller than longships, both in terms of size and the number of crew. The crew of such a unit numbered only 20-30 sailors. The 30 ships with which Ingvar left Sweden, and later also the Kievan Rus, could carry between 600 and 900 people. That seems to confirm the above-mentioned findings of M.G. Larsson. We do not know much about the captains of those vessels. The Saga names four of them: Hjalmvigi, Soti, Ketil, and Valdimar. In addition, the Saga also mentions a ship commanded by two priests. Holmstein and Banki/Baggi are the only captains and owners of their own ships who are named on the runic stones. On the runestones which I examined, in addition to that, two helmsmen and one crew member were named by name. Undoubtedly, these were people experienced in sea expeditions and sailing on rivers, which is confirmed by one record of runestone No. U 654: Es kunni val knoerri styra.

\footnotetext{
${ }^{30}$ S. BLÖNDAL, Varangians..., p. 105; S. WierzBiŃsKi, U boku..., p. 158.

${ }^{31}$ M.G. LARsson, Yngvarr's..., p. 104; IDEM, Vart for Ingvar den vittfarne?, For 78, 1983, p. 98-99.

32 IDEM, Yngvarr's..., p. 103.

${ }^{33}$ IDEM, Ingvar the Fartraveller..., p. 36-37, 40-43.

${ }^{34}$ J. ShePard, Yngvarr's..., p. 230-259.

${ }^{35}$ Ibidem, p. 276-279; S. WierzBiŃski, U boku..., p. 160; С. МАРКАРян, По поводу..., p. 151-152.
} 
Was their commander equally experienced? Ingvar, from the age of nine, served King Olaf. As a boy, he received a ship, which, according to the Saga, he had to hand over to his father. Then, we see him again as a young man, who is headed with three ships for Semigalia, which is located on the other side of the Baltic Sea. This was probably his first sea expedition. After returning, he managed to convince nearly 1,000 Swedes to accompany him on the expedition to the Saracens' land. Therefore, he must have been a charismatic leader and must have had the skills necessary for sailing and commanding ships. According to the Saga, he stayed in Holmgard for a long time to learn the hydrography of the most important rivers of the Rus. He also learned there foreign languages needed in his further journey. Which river did he choose to sail south? Was it the Volga or the Dnieper, as the aforementioned researchers believe?

Another possibility is that it was the Don, which flows into the Sea of Azov. This river is so important because it runs between the Dnieper and the Volga, and its mouth, giving to the sea in Taganrog Bay, is located near the other large rivers of this region: Kalmius and Mius. To the south, Tmutarakan was located, a medieval Kievan Rus principality and trading town which controlled the Cimmerian Bosporus, as well as the estuary of the Kuban River, at Temryuk Bay. The Kuban is a river whose sources are in the heart of the Caucasus's mountains, and to this day it is navigable all the way to the city of Krasnodar. It was also the former land of the medieval Alans, as well as the kingdom of Zichia. Maybe the cities of Citopolis and Heliopolis, which appear in a Saga, should be looked for around this area. Located in Zichia is the city of Nikopsis, which was an important Byzantine outpost in the Caucasus $^{36}$. Rus prince Mstislav of Chernigov (988-after 1035) ruled these lands and cities during the time of Ingvar's journey. Maybe it is him or one of his direct successors that can be seen as the prototype of king Jolf from the Saga. Mstislav also ruled a number of Caucasus peoples, whom he had conquered or forced to recognize his authority. They were the peoples from Kasogians and Khazars tribes ${ }^{37}$. Prince Mstislav, like king Jolf, who, according to the Saga, knew many languages, including Greek, would have been a polyglot of sorts as he ruled over such different communities (...Sá var skrýddr konungs skrúða ok mœlti margar tungur... Dá moelti hann nokkur orð á girsku. Yngvarr skildi, at hann hét Jólfr ok var ór borginni Heliópólim / ...He was robed as a king, and spoke many tongues... Then he spoke a few words in Greek. Yngvar understood that he was called Jolf and was from the city of Helipolis) ${ }^{38}$. This ruler also had a long-standing feud with his brother, which concluded with the battle of Listven near Chernigov in 1024, where his troops

\footnotetext{
${ }^{36}$ O. Pritsak, Zichia, [in:] ODB, vol. III, p. 2226-2227.

${ }^{37}$ The Russian Primary Chronicle. Laurentian Text, trans. S.H. Hazzard Cross, O. Sherbowitz-Wetzor, Cambridge Mass. 1953, p. 134-135.

${ }^{38}$ Yngvars saga víðförla, 5.
} 
clashed with the Varangians of Jaroslav the Wise, and the latter lost that battle ${ }^{39}$. Mstislav also cooperated with the Byzantine fleet from 1016. In this year, the joint attack carried out by the Byzantines and Mstislav mainly targeted the eastern part of the Crimea and the city of Kerch. This city was controlled by the Khazars, who remained there after the fall of their khaganate, which was destroyed by Mstislav's grandfather Svyatoslav in the $10^{\text {th }}$ century. The leader of the Crimean Khazars, whose capital was in this city, was Georgius Tzul. The joint Byzantine-Rus expedition was successful and the occupation of the aforementioned city by Mstislav followed ${ }^{40}$. It is possible that the round ships mentioned in the Saga, which Jolf had at his disposal, were units used for navigation on the Sea of Azov and the rivers flowing into it by the Khazars, over whom the prince of Tmutarakan ruled (...En er leið sumarit, sáu peir fjölda skipa róa í mót sér. Pau váru öll kringlótt ok umhverfis árar fyrir borðum. Peir lögðu svá i mót, at Yngvarr átti einskis kost nema biða i stað, pví at svá fóru skip peira sem fugl flygi / But as summer passed, they saw many boats rowing towards them. They were all round with oars on every side. They steered towards them, so that Yngvar had no choice but to wait there for them, because their boats seemed to fly like birds $)^{41}$.

Therefore, the wicked pirates living downstream, mentioned by Jolf, could have simply been Byzantine sailors, whose task was to block the movement down the river. The Saga mentions five pirate ships masked as islands, which attacked Ingvar and his men. Leo the Wise (886-912), a Byzantine Emperor, mentions in his Tactica that in order to preserve the efficiency of the fleet, it should be divided into subdivisions of 3 to 5 dromons, which should be under the command of an archon in the rank of comes of the fleet, a man answering to the fleet commander ${ }^{42}$. The Byzantine dromons could have also been armed with Greek fire and a ballista to throw stones at enemies. Such a 5-strong naval vessel squadron was able to cooperate with the allies of the Byzantines away from the home base. The crews of these five ships would have been around 600-800 people (considering that there could be between 140 and 200 oarsmen, sailors, and marines aboard an ordinary dromon $)^{43}$. Therefore, it was a significant military contingent,

\footnotetext{
${ }^{39}$ The Russian Primary Chronicle..., p. 134-136.

${ }^{40}$ Ioannis Scylitzae Synopsis Historiarum, ed. I. Thurn, Berlin-New York 1973 [= CFHB, 5], p. 354. 88-93; A. Poppe, Le prince et l'Église en Russie de Kiev depuis la fin du Xe siècle et jusqu'au début du XIP tiède, АРН 20, 1969, р. 95-119; Л. Войтович, Князівські династії Східної Європи (кінець IX - початок XVI cm.), Львів 2000, p. 150-152; A. VAsiliev, The Goths in the Crimea, New York 1936, p. 134; J. BonareK, Romajowie i obcy w kronice Jana Skylitzesa. Identyfikacja etniczna Bizantyńczyków i ich stosunek do obcych w świetle kroniki Jana Skylitzesa, Toruń 2003, p. 163; S. WierzbińsKi, U boku..., p. 89.

${ }^{41}$ Yngvars saga vídförla, 5.

${ }^{42}$ The Taktika of Leo VI, XIX, 25, ed. et trans. G.T. Dennis, Washington 2010 [= CFHB.SW, 49], p. 512-513.

${ }^{43}$ J. Pryor, E.M. Jeffreys, The Age of the $\triangle P O M \Omega N$. The Byzantine Navy ca. 500-1204, Leiden-Boston 2006, p. 254-260.
} 
which could have easily acted as an ally to Mstislav. Later, possibly during the reign of the prince's successor in Tmutarakan, the relations with the Rus must have deteriorated, and perhaps this squadron of Byzantine ships deserted Emperor and went into common robbery, which is why the Saga gave them the name of pirates. The desertion of these sailors and their transition to pirate activities would also be evidence of a much earlier crisis in the Byzantine naval forces, including those operating in the Black Sea, preceding the reign of Constantine IX (1042-1055).

To summarize, we are looking at indirect proof of the activity of Byzantine ships mentioned by the Saga. Where, then, could a potential clash with the Byzantines have occurred? There are several possible locations, one of them being the estuary of Don, and another the Kuban. The location of the aforementioned events and places in this part of the Black Sea coast seems to be confirmed by the subsequent choices of some of Ingvar's men, who, after his death, headed for the Rus or Constantinople. Of course, some researchers see the use of Greek fire by the pirates as the confirmation of the participation of Ingvar's fleet in the Rus expedition to Constantinople in 1043, where such weapons were used against them ${ }^{44}$. The Saga mentions the fork of the river, not the fight in the strait, which was the case of the sea battle near the capital of Byzantium. Also, the Byzantines, unlike the pirates, did not mask their ships fighting against the Rus in 1043.

\section{Bibliography}

\section{Primary Sources}

Flateyjarbok, ed. G. Vigfússon, C.R. Unger, Christiana 1868.

Ioannis Scylitzae Synopsis Historiarum, ed. I. Thurn, Berlin-New York 1973 [= Corpus fontium historiae byzantinae, 5].

Konungs annáll “Annales islandorum regii”, ed. H.B. Goodwin, Uppsala 1906.

Lögmannsannáll (ásamt Nýjaannál), ed. G. Jónsson, Reykjavík 1948, http://heimskringla.no/Lögmannsannáll_(ásamt_Nýjaannál) [10 XII 2018].

Oddr SnOrrason, The Saga of Olaf Tryggvason, trans. T.M. Andersson, ed. K. Bragadóttir, Ithaca 2003.

Rewriting Caucasian History. The Medieval Armenian Adaptation of the Georgian Chronicles. The Original Georgian Texts and the Armenian Adaptation, ed. et trans. R.W. Thomson, Oxford 1996.

Rundata 3.1 for Windows, http://www.nordiska.uu.se/forskn/samnord.htm [10 XII 2018].

The Russian Primary Chronicle. Laurentian Text, trans. S.H. Hazzard Cross, O. Sherbowitz-Wetzor, Cambridge Mass. 1953.

Sveriges Runinskrifter, III, Södermanlands Runinskrifter, ed. E. BRATE, E. Wessén, Stockholm 1924-1936.

${ }^{44}$ J. SHEPARD, Yngvarr's..., p. 234. 
Sveriges Runinskrifter, VII, Upplands Runinskrifter del 2, ed. E. WessÉn, S. JANsson, Stockholm 1943-1946.

Sveriges Runinskrifter, VIII, Upplands Runinskrifter del 3, ed. E. Wessén, S. Jansson, Stockholm 1949-1951.

The Taktika of Leo VI, ed. et trans. G.T. Dennis, Washington 2010 [= Corpus fontium historiae byzantinae. Series Washingtonensis, 49].

Yngvars saga víðförla, http://heimskringla.no/wiki/Yngvars_saga_viðförla [10 XII 2018].

Yngvars saga víðförla, https://www.snerpa.is/net/forn/yngvar.htm [10 XII 2018].

\section{Secondary Literature}

Atкinson I., The Viking Ships, Cambridge 1980.

Blöndal S., Varangians of Byzantium. An Aspect of Byzantine Military History, trans. B.S. Benedikz, Cambridge 1978.

BonareK J., Romajowie i obcy w kronice Jana Skylitzesa. Identyfikacja etniczna Bizantyńczyków i ich stosunek do obcych w świetle kroniki Jana Skylitzesa, Toruń 2003.

Clunies Ross M., Old Icelandic Literature and Society, Cambridge 2000.

ELLERTSSON B., Íslensk-pýsk orðabók. Isländisch-Deutsches Wörterbuch, Reykjavik 1993.

Firesen O. Von, Hvem var Yngvarr enn vidforli?, "Fornvännen. Tidskrift för svensk antikvarisk forskning" 5, 1910, p. 199-209.

Glazyrina G., On Heliopolis in Ingvars saga viðförla, [in:] Scandinavian and Christian Europe in the Middle Ages. Papers of the $12^{\text {th }}$ International Saga Conference, ed. R. SimeK, J. Meurer, Bonn 2003, p. 175-178.

Jesch J., Ships and Men in the Late Viking Age. The Vocabulary of Runic Inscriptions and Skaldic Verse, Woodbridge 2008.

Larsson M.G., Early Contacts between Scandinavia and the Orient, “The Silk Road Journal” 9, 2011, p. $122-142$.

Larsson M.G., Ingvar the Fartravellers Journey: Historical and Archaeological Sources, [in:] Between East and West. Early Contacts between Scandinavia and Caucasus, ed. M.G. LARsson, UppsalaRimbo 2013, p. 36-48.

LARsson M.G., Ingvarstågets arkeologiska bakgrund, "Fornvännen. Tidskrift för svensk antikvarisk forskning" 81, 1986, p. 98-113.

Larsson M.G., Vart for Ingvar den vittfarne?, "Fornvännen. Tidskrift för svensk antikvarisk forskning" 78, 1983, p. 95-104.

Larsson M.G., Yngvarr's Expedition and the 'Georgian Chronicle, "Saga Book of the Viking Society for Northern Research” 22, 1986, p. 98-108.

Markarjan S., Po povodu ličnosti predvoditelja družiny vikingov na Kavkaze v XI veke, "Patma-Banasirakan Handes. Revue historico-philologique" 103, 1, 2000, p. 150-158.

McGinnis D.I., The Vikings in the East: Ingvars sagavifförla, [in:] A Selection from the Papers Presented at the First Annual Meeting Held at Ottawa 1982, ed. E.W. LaIne, Ottawa 1983, p. 79-86.

Poppe A., Le prince et l'Église en Russie de Kiev depuis la fin du Xe siècle et jusqu'au début du XIP tiède, "Acta Poloniae Historica" 20, 1969, p. 95-119.

Pritsak O., The Origin of Rus', vol. I, Old Scandinavian Sources other than the Sagas, Cambridge Mass. 1981. 
Pritsak O., Zichia, [in:] The Oxford Dictionary of Byzantium, vol. III, ed. A. Kazhdan et al., New York-Oxford 1991, p. 2226-2227.

Pryor J., Jeffreys E.M., The Age of the $\triangle P O M \Omega N$. The Byzantine Navy ca. 500-1204, Leiden-Boston 2006.

Shepard J., Yngvarr's Expedition to the East and a Russian Inscribed Stone Cross, "Saga Book of the Viking Society for Northern Research" 21, 1982, p. 222-292.

Vasiliev A., The Goths in the Crimea, New York 1936.

VoJTovič L., Knjaziv'ski dynastii Schidnoï Jevropy (kinec' IX - počatok XVI st.), L'viv 2000.

WierzBiŃski S., U boku bazyleusa. Frankowie i Waregowie w cesarstwie bizantyńskim w XI w., Łódź 2019 [= Byzantina Lodziensia, 37].

\begin{abstract}
The Journey to the East of the Viking Ingvar the Far-Traveled is one of the events that fit into the history of medieval relations of the Scandinavians with the world of Byzantium. It was a fateful expedition taking place between 1036 and 1041, and to this day it is a source of many controversies and speculations of researchers. The findings of the present paper suggest that the journey did not necessarily proceed to the lands of the Saracens or Byzantium but may have been part of the game played by Constantinople with its ally Tmutarkan, which opposed Jaroslav the Wise, these events unfolding in the north-eastern waters of the Black Sea.
\end{abstract}

Keywords: Byzantium, Ingvar the Far-Traveled, Viking ships, Dromons, Caucasus.

Marcin Böhm

University of Opole Faculty of Social Studies

Institute of History ul. Strzelców Bytomskich 2 45-084 Opole, Poland mabohm@wp.pl 